\title{
MOLECULAR IDENTIFICATION AND CLONAL RELATION OF ATYPICAL ISOLATE Aeromonas salmonicida USING RESTRICTION FRAGMENT LENGTH POLYMORPHISM (RFLP)
}

\author{
Riza Priyatna\#, Indaryulianto, S. , and Kurniasih \\ Faculty of Veterinary Medicine, Gadjah Mada University, Yogyakarta
}

(Received 4 April 2011; Accepted 26 August 2011)

\begin{abstract}
Aeromonas salmonicida is responsible in many cases of furunculosis outbreaks resulting in economic loss of freshwater aquaculture. Four isolates of $A$. salmonicida have been isolated from fish collected in four different regions in Indonesia and its clonal relation has yet to be determined. In the research, $\mathrm{A}$. salmonicida isolates and ATCC atypical isolate as the control had been checked for their clonal relation using Restriction Fragment Length Polymorphism (RFLP) method in which restriction enzyme of Alul, Haell, Mbol and Ehel were used. PCR test results using the primers 16S rDNA amplicon gave a positive response to the $1300 \mathrm{bp}$ band. The result of RFLP analysis showed that $A$. salmonicida atypical isolates from Indonesia represent subspecies smithia except isolates from C. macropomum in Yogyakarta in MS and 16S rDNA regions. Isolates from Jambi, Pontianak and Semarang showed a slight variation on enzyme restriction sites. Isolates number 2, 3, 4 and 5 had the same restriction sites using Alul enzyme with MS primer. The restriction enzymes that could give the best result for RFLP method of $A$. salmonicida were Haelll, Mbol and Ehel.
\end{abstract}

\section{KEYWORDS: A. salmonicida, furunculosis, PCR, RFLP, restriction enzyme}

\section{INTRODUCTION}

Aer omonas salmonicida is the agent of etiological furunculosis disease which strikes many fish farmings and has caused a significant economic loss in freshwater aquaculture (McCarthy \& Roberts, 1980; O'Brien et al., 1994). Typical and atypical terms of $A$. salmonicida are used to differentiate among strains causing furunculosis on salmon and other strains causing furunculosis on both Salmon and other fishes (Austin \& Austin, 1999; Inglis et al., 1993).

Clinical signs of furunculosis include septicemia, losing of appetite, weakness and ne- croses, and hemorrhagic of gill, muscle and intestine (Hiney \& Olivier, 1999). This bacterium has also been attributed to disease of ulcer on carp and flat fish and also erythrodermatitis on carp fish (Austin \& Austin, 1999).

A. salmonicida is Gram-negative bipolar, having the character of optional anaerobic, motion less, no spore, no capsule, in form of short rod, fairish 1,3-2,0 $\mu$ best growth at temperature $18^{\circ} \mathrm{C}-25^{\circ} \mathrm{C}$ (Sakazaki \& Ballows, 1981; Untergasser, 1989; Inglis et al., 1993; Austin \& Austin, 1999). Aeromonas salmonicida can grow in various media for example

\footnotetext{
\# Corresponding author. Faculty of Veterinary Medicine, Gadjah Mada University, JI. Fauna No. 2, Karangmalang, Yogyakarta, Indonesia. Tel.: + 62274560861

E-mail address: riz_pribpp@yahoo.co.id; fkh@ugm.ac.id
} 
Trypticase Soy Agar (TSA) and Brain Heart Infussion Agar (BHIA) (Inglish et al., 1993; Austin et al., 1998).

Using RFLP of $16 \mathrm{~S}$ rRNA gene, specific pattern-type for all strains of species $A$. salmonicida can be determined (Borrel et al., 1997; Figueras et al., 2000). This method used two endonucleus simultan Alul (AGCT), Haelll, Narl and Mbol (GATC) (Borrell et al., 1997). The addition of two enzymes type Narl (GGCGCC) and Haelll (GGCC) were needed to differentiate gene $16 \mathrm{SrDNA} A$. salmonicida, $A$. encheleia of HG 11 (group hybridization 11) of Aeromonas spp. (Figueras et al., 2000).

The research was aimed to study clonal relationship of all atypical isolates of $A$. salmonicida using PCR and Restriction Fragment Length Polymorphism (RFLP) from several areas in Indonesia.

\section{MATERIALS AND METHODS}

\section{Fish}

Fish samples used in this research was 470 individuals of goldfish (Carpio cyprinus) sized $\pm 10 \mathrm{~cm}$ in average weight. The fish was collected from several freshwater areas in Indonesia characterized by the occurrences of $A$. salmonicida.

\section{Isolate}

Aeromonas salmonicida used were isolates from ATCC (isolate 1), C. macropomum in Yogyakarta (isolate 2), O. ni loticus in Jambi (isolate 3), C. carpio in Pontianak (isolate 4), and O.gour amy in Semarang (isolate 5).

As the control was atypical isolate of $A$. salmonicida subsp. smithia (Austin et al. Product of Americans Type Culture Collection (ATCC) Number : 49393 by RFLP).

\section{PCR}

Materials for DNA Amplification and Electrophoresis: easy DNA mini column (Qiagen), PCR Kit (Promega) for PCR Amplification of 16S rDNA using the primers 1A (5'CGTTGGATATGGCTCTTCCT- 3') and 16S rDNA 2A (5'- CTCAAAACGGCTGCGTACCA- 3') (Hiney et al., 1992); primer MS1 (5'AGGATGGCCTGCTCGTCACC- 3') and MS2 (5'GTGACG CCCAGGCCA TCCTC- 3 ') (Fehr et al., 2007).

\section{RFLP}

Materials used during the RFLP examination were : enzyme of Alul (5'AGCT), Haelll (5'GGCC), Mbol (5'NGATCN) and Ehel (5'GGCGCC), acetic acid glacial, buffer loading (consisted of $0,25 \%$ blue bromphenol, 0,25\%cyanol xylene and 30 \% glyserol), 4\% gel agarose metaphor (PMC Bioproduct) in 0,5 TBEx (Tris- Borate- EDTA) Buffer (Metaphor Agarose Gel stained using bromide ethidium $0,5 \mu \mathrm{g} / \mathrm{ml}$ ), $\mathrm{dH}_{2} \mathrm{O}$, sol I for $100 \mathrm{ml}\left(\mathrm{AgNO}_{3}\right.$ 0,15 gr $+37 \%$, sol Il for $100 \mathrm{ml}$ $\left(\mathrm{Na}_{2} \mathrm{CO}_{3}: 3 \mathrm{gr}+\right.$ Formaldehyde $151 \mathrm{ml}+$ sodium thiosulfat $5 \mu \mathrm{g} / 261 \mathrm{mg} / \mathrm{ml}$ where is endconcentration $2 \mathrm{mg} / \mathrm{ml}$ ) and $8 \%$ polycrylamide gel.

\section{Characterization}

Characterization of bacterium was done through identification of morphology, such as Gram test, motility and ability of fermentation, IMVIC, and biochemical examination using biochemistry test.

\section{RESULTS AND DISCUSSION}

\section{Results}

The results of $16 \mathrm{~S}$ rDNA amplification with a primer on all isolates of $A$. salmonicida gave a positive response to the $1300 \mathrm{bp}$ band. The results also showed that isolates from Yogyakarta, Semarang, Pontianak and Jambi has similarities to isolates of $A$. salmonicida. This ATCC isolates amplified with the characterization of isolates from Indonesia indicated A. salmonicida (Figure 1).

The results of the test using RFLP on four isolates of atypical A. salmonicida from several regions in Indonesia and isolates from the ATCC with MS primary did not show any band with a restriction enzyme Alul (Figure 2 and 3). Enzymes Alul did not give a positive response to the five isolates because this enzyme has no restriction sites of DNA on all isolates. This can occur because of several factors that affect the action of the enzyme, namely: temperature $\left(0^{\circ} \mathrm{C}\right.$ : no activity; $38^{\circ} \mathrm{C}-40^{\circ} \mathrm{C}$ : increased enzyme activity, $>38^{\circ} \mathrm{C}$ : decreased enzyme activity; $60^{\circ} \mathrm{C}$ : enzyme activity is discontinued), water, $\mathrm{pH}$, concentration of enzyme (speed the process of formation or decomposition of the molecule following the concentration of enzyme substrate) and inhibitors (Brown, 2002). 


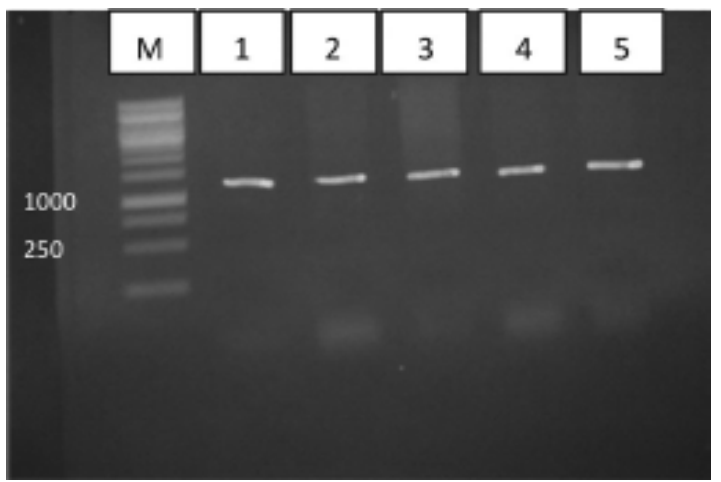

Figure 1. Results amplification A.salmonicida 4 isolates from Indonesia and from ATCC in the area of $16 \mathrm{~S}$ rDNA bands appear at 1300 bp. (M: marker; 1: isolate ATCC; 2: Yogyakarta isolates; 3: Semarang isolates; 4 : isolates Pontianak; 5 : isolates Jambi

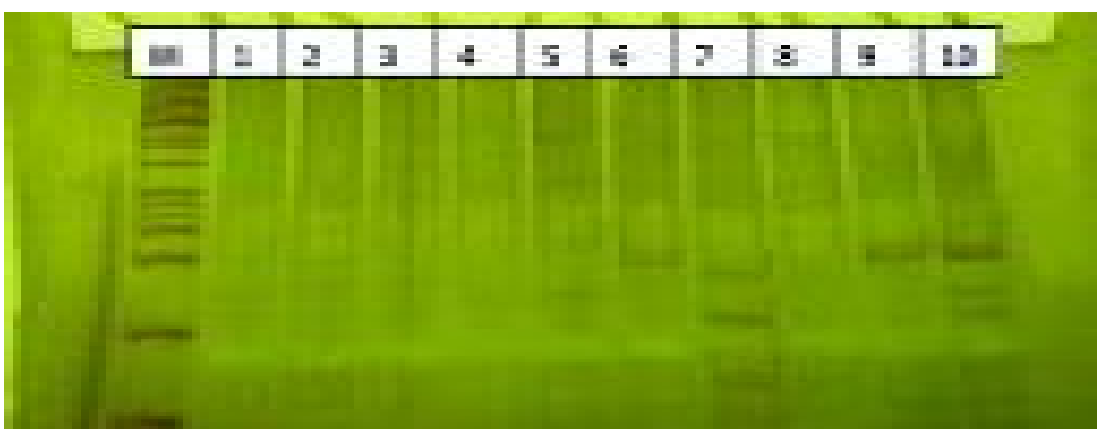

Figure 2. Result of RFLP- PCR method with MS primer of A.salmonicida, using Alul enzyme (lanes 1-5) and using Haelll enzyme (lanes 6- 10) , M= marker; 1 dan 6 : ATCC isolate, 2 and 7 : Yogyakarta isolate, 3 and 8 : Semarang isolate, 4 and 9 : Pontianak isolate, 5 and 10 : Jambi isolate

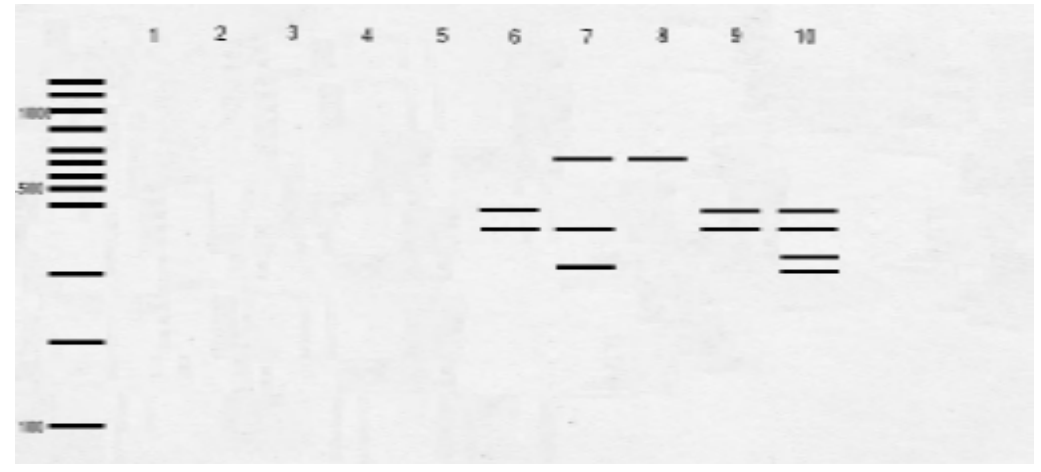

Figure 3. Scheme of RFLP-PCR method using the primary MS A.salmonicida, using enzymes Alul (lanes 1-5) and enzymes Haell (lanes 6- 10), $\mathrm{M}=$ marker; 1 dan 6 : ATCC isolate, 2 and 7 : Yogyakarta isolate, 3 and 8 : Semarang isolate, 4 and 9 : Pontianak isolate, 5 and 10 : Jambi isolate 
Haell restriction enzyme showed similarity with isolates no. 1 and 4. Isolates 2, 3, 5 had very different places of restrictions on each other (Figure 4 and 5). Side- cutting enzymes used is shown in Table 1.
Haell enzyme was used for PCR- RFLPalong with the MS and 16SrDNA primers. With the MS primer, ATCC isolates showed the same restriction sites in isolates 4 , while the isolates 2,3 , and 5 respectively show different restriction

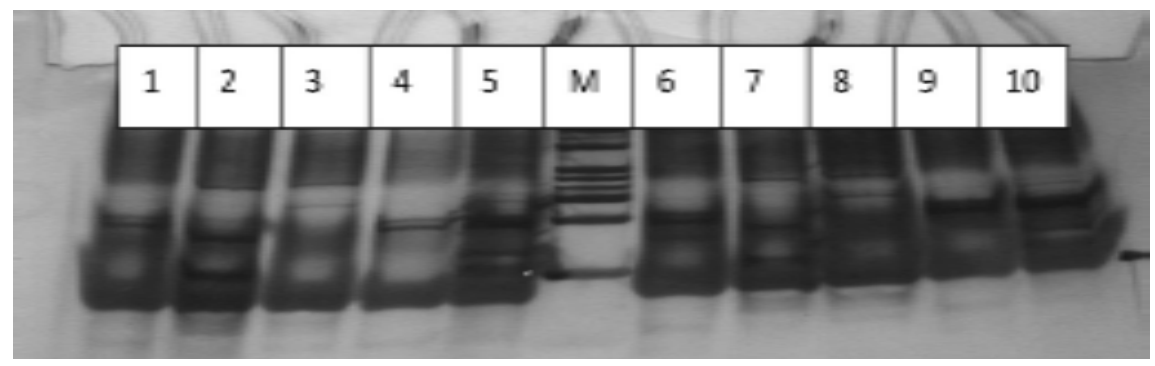

Figure 4. RFLP-PCR method of A. salmonicida atypical isolate using HaellI enzyme with MS primer (lanes 1- 5) and PCR in 16S region (lanes 6- 10). $\mathrm{M}=$ marker; 1 and 6 : ATCC isolate, 2 and 7 : Yogyakarta isolate, 3 and 8 : Semarang isolate, 4 and 9 : Pontianak isolate, 5 and 10 : Jambi isolate

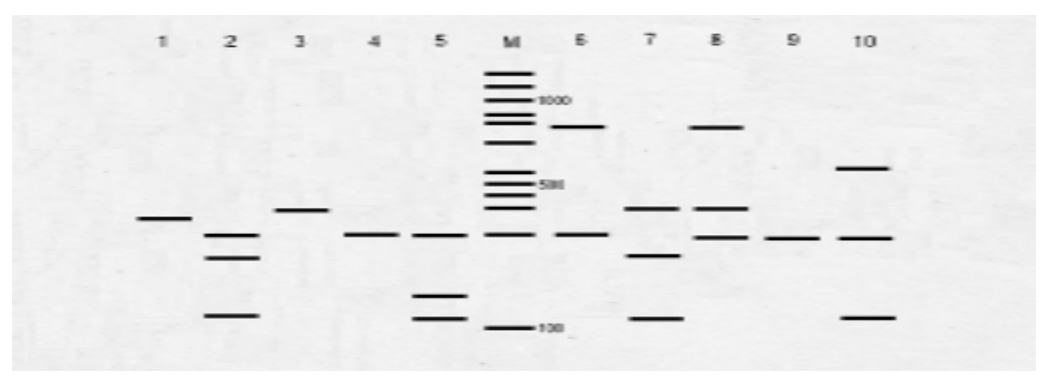

Figure 5. Scheme of RFLP- PCR method to isolate atypical A. salmonicida using the enzyme Haelll with MS primer (lanes 1- 5) and the PCR in 16S region (lanes 6- 10). $M=$ marker; 1 and 6 : ATCC isolate, 2 and 7 : Yogyakarta isolate, 3 and 8 : Semarang isolate, 4 and 9 : Pontianak isolate, 5 and 10 : Jambi isolate

Table 1. Recognition results of the various restriction enzyme sites of the samples

\begin{tabular}{|c|c|c|c|}
\hline $\begin{array}{l}\text { Restriction } \\
\text { enzyme }\end{array}$ & $\begin{array}{c}\text { Recognition } \\
\text { site }\end{array}$ & Cutting side & Cut result \\
\hline \multirow[t]{2}{*}{ HaellI } & 5'GGCC & $5^{\prime} \ldots \mathrm{GG} \downarrow \mathrm{CC} \ldots 3^{\prime}$ & Positive \\
\hline & 3'CCGG & $3^{\prime} \ldots \mathrm{CC} \uparrow \mathrm{GG} \ldots 5^{\prime}$ & \\
\hline \multirow[t]{2}{*}{ Alul } & 5'AGCT & $5^{\prime} \ldots \mathrm{AG} \downarrow \mathrm{CT} \ldots 3^{\prime}$ & Negative \\
\hline & 3'TCGA & $3^{\prime} \ldots \mathrm{TC} \uparrow \mathrm{GA} \ldots 5^{\prime}$ & \\
\hline \multirow[t]{2}{*}{ Mbol } & 5'NGATCN & $5^{\prime} \ldots \mathrm{N} \downarrow$ GATCN $\ldots . .3^{\prime}$ & Positive \\
\hline & 3'NCTAGN & $3^{\prime} \ldots$ NCTAG 4 N...5 $5^{\prime}$ & \\
\hline \multirow[t]{2}{*}{ Ehel } & 5'GGCGCC & $5^{\prime} \ldots \mathrm{GGC} \downarrow \mathrm{GCC} \ldots 3^{\prime}$ & Positive \\
\hline & 3'CCGCGG & $3^{\prime} \ldots$ CCG 4 CGG.... $3^{\prime}$ & \\
\hline
\end{tabular}


sites. The amplification with 16S rDNA primer showed that 5 isolates of $A$. salmonicida have mutually different restriction sites. So, it can be concluded that the five isolates had a variety of strains in the area of the 16S rDNA gene (Figure 4 and 5).

In RFLP testing using Mbol and Ehel enzyme on 5 isolates of atypical A. salmonicida, isolates 3,4 , and 5 showed similar results compared to ATCC isolate (1). There was only one isolate which was isolate number 2 (isolates from Yogyakarta) that had different restriction sites compared to four isolates (Figure 6 and 7). The same result was also found in the use of enzymes Ehel. 16S rDNA nucleotide sequences at 118-207 bp cut on Mbol enzyme and the enzyme Ehel 452- 1050 bp were consistent with the results of the study by
Martinez- Murcia et al. (1992) and Borell et al. (1997) (Table 2).

\section{Characterization}

Isolation and identification of $A$. salmonicida from several areas in Indonesia showed the same result.

Biochemical test against all isolates of atypical A. salmonicida suggests that there are similarities between isolates of atypical A. salmonicida subsp. smithia and ATCC by looking on the test results of ornithin dexarboxylase (- ), the gas produced TSI (- ), VogesProskauer test (-), acid from arabinose (+), sacrose (+), acid from D- sorbitol (SOR) (- ), acid from lactose $(-)$, catalase $(+)$, its ability to grow at $37^{\circ} \mathrm{C}(-)$, indole $(-)$, methyl red $(-), O / F(F)$, motility (-) and utilization of citrate (-) (Table 3).

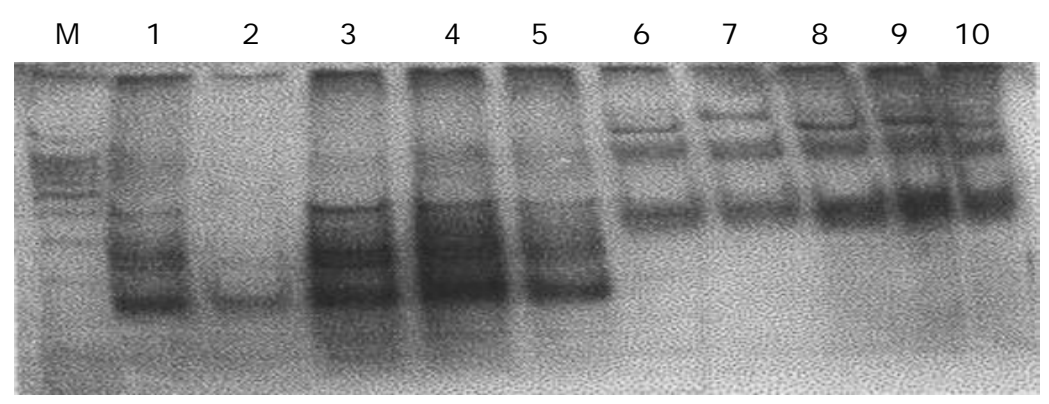

Figure 6. RFLP- PCR method of A. salmonicida atypical isolate with MS primer using Mbol enzyme (lanes 1-5) and using Ehel enzyme (lanes 6 - 10). $M=$ marker; 1 and 6 : ATCC isolate, 2 and 7 : Yogyakarta isolate, 3 and 8 : Semarang isolate, 4 and 9 : Pontianak isolate, 5 and 10 : Jambi isolate

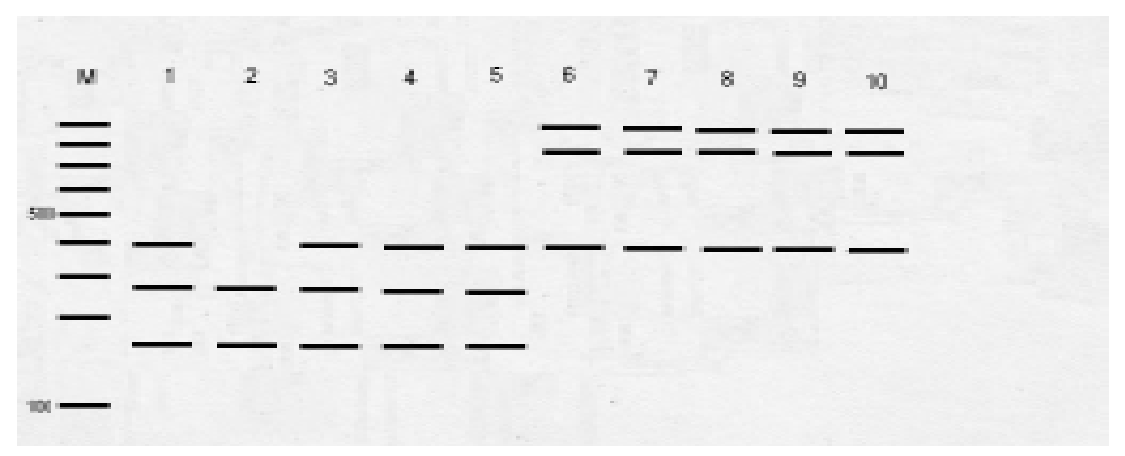

Figure 7. Scheme of RFLP- PCR method to isolate atypical A. salmonicida with primary MS using enzyme Mbol (lanes 1- 5) and using the enzyme Ehel (lanes 6- 10). $M=$ marker; 1 and 6 : ATCC isolate, 2 and $7:$ Yogyakarta isolate, 3 and 8 : Semarang isolate, 4 and 9 : Pontianak isolate, 5 and 10 : Jambi isolate 
Indonesian Aquaculture Journal Vol.6 No.2, 2011

Table 2. Comparison with the pattern of restriction enzyme endonukleus of A. salmonicida isolates

\begin{tabular}{|c|c|c|c|c|}
\hline \multirow{2}{*}{ Isolate } & \multicolumn{4}{|c|}{ Enzime } \\
\hline & Alu I & Hae III & Mbo I & Ehe I \\
\hline ATCC & - & $360 b p, 380$ bp & $\begin{array}{l}180 \text { bp, } 380 \text { bp, } \\
400 \text { bp }\end{array}$ & $750 \mathrm{bp}, 850 \mathrm{bp}$ \\
\hline Yogyakarta & - & $\begin{array}{l}300 \text { bp, } 360 \text { bp, } \\
700 \text { bp }\end{array}$ & 180 bp, 280 bp & $750 \mathrm{bp}, 850 \mathrm{bp}$ \\
\hline Semarang & - & $\begin{array}{l}300 \text { bp, } 320 \text { bp, } \\
360 \text { bp, } 380 \text { bp }\end{array}$ & $\begin{array}{l}\text { 180, bp } 380 \text { bp, } \\
400 \text { bp }\end{array}$ & 750 bp, 850 bp \\
\hline Pontianak & - & 360 bp, 380 bp & $\begin{array}{l}180 \text { bp, } 380 \text { bp, } \\
400 \text { bp }\end{array}$ & $750 \mathrm{bp}, 850 \mathrm{bp}$ \\
\hline Jambi & - & $700 \mathrm{bp}$ & $\begin{array}{l}180 \text { bp, } 380 \text { bp, } \\
400 \text { bp }\end{array}$ & 750 bp, 850 bp \\
\hline
\end{tabular}

Table 3. Result of biochemical characterization of A. salmonicida isolated from goldfish collected from Pontianak, Semarang, Yogyakarta, and Jambi

\begin{tabular}{|c|c|c|c|c|c|}
\hline \multirow{2}{*}{ Test Media } & \multicolumn{5}{|c|}{ A. Salmonicida atypical isolotes } \\
\hline & Pontianak & Semarang & Yogyakarta & Jambi & ATCC \\
\hline Brown Pigmen & + & + & + & + & + \\
\hline Blood Agar & $\beta$ haemolysis & $\beta$ haemolysis & $\beta$ haemolysis & $\beta$ haemolysis & $\beta$ haemolysis \\
\hline Mc. Conkey & + & + & + & + & + \\
\hline Agar & (colored) & (colored) & (colored) & (colored) & (colored) \\
\hline \multirow[t]{2}{*}{ Morfologi } & Rod & Rod & Rod & Rod & Rod \\
\hline & Gram - & Gram - & Gram - & Gram - & Gram - \\
\hline Voges-Proskauer & - & - & - & - & - \\
\hline Motility & - & - & - & - & - \\
\hline Katalase & + & + & + & + & + \\
\hline $\begin{array}{l}\text { Fermentativ } \\
\text { Metabolisme }\end{array}$ & + & + & + & + & + \\
\hline Oxidase & + & + & + & + & + \\
\hline \multicolumn{6}{|l|}{ TSI Agar : } \\
\hline -Buff & As & As & As & As & As \\
\hline -Slant & Alk & Alk & Alk & Alk & Alk \\
\hline$-\mathrm{H} 2 \mathrm{~S}$ & - & - & - & - & - \\
\hline Indol & - & - & - & - & - \\
\hline MR & - & - & - & - & - \\
\hline Sodium citrat & - & - & - & - & - \\
\hline Urea & - & - & - & - & - \\
\hline $\mathrm{O} / \mathrm{F}$ & $\mathrm{F}$ & $\mathrm{F}$ & $\mathrm{F}$ & $F$ & $\mathrm{~F}$ \\
\hline Agar $2 \% \mathrm{NaCl}$ & + & + & + & + & + \\
\hline Agar $4 \% \mathrm{NaCl}$ & - & - & - & - & - \\
\hline Gelatin & + & + & + & + & + \\
\hline
\end{tabular}


Table 3. (Continued)

\begin{tabular}{lccccc}
\hline \multirow{2}{*}{ Test Media } & \multicolumn{5}{c}{ A. Salmonicida atypical isolotes } \\
\cline { 2 - 6 } & Pontianak & Semarang & Yogyakarta & Jambi & ATCC \\
\hline DNase & + & + & + & + & + \\
Grown at 370C & - & - & - & - & - \\
Glukosa & + & + & + & + & + \\
Laktosa & - & - & - & - & - \\
Sukrosa & + & + & + & - & + \\
Raffinosa & - & - & - & - & - \\
Sorbitol & - & - & - & + & + \\
Maltosa & + & + & + & + & + \\
Arabinosa & + & + & + & - & - \\
Dulcitol & - & - & - & - & - \\
Ornithin & - & - & - & \\
\hline
\end{tabular}

\section{Discussion}

Haelll enzyme provided a better result on DNA testing of MS gene RFLP and 16S rRNA of A. salmonicida. RFLP testing using enzyme Mbol and Ehel on 5 isolates of atypical A. salmonicida showed similar results for isolates 3,4 , and 5 with ATCC isolates (1). Isolates from Yogyakarta (2) has a different restriction site compared to the other four isolates. The same result was also found in the use of enzymes Ehel. The result of 165 rRNA nucleotide sequence cutting in the enzyme Mbol 118- 207 bp and 452- 1050 bp in Ehel enzymes were consistent with the results of the study by Martinez- Murcia et al. (1992) and Borrell et al. (1997). Based on these results, it showed a specific pattern of relationships which are very close in all isolates of atypical $A$. salmonicida collection from several regions in Indonesia with atypical isolates of $A$. salmonicida subsp. smithia from ATCC. Application of RFLP method does not only uncover patterns that can be grouped in a single subspecies (Huys et al., 1997), but also can clarify phenotype pattern of 16S rRNA gene variation within A. salmonicida subsp. smithia (Graf, 1999).

In this regard, determination of endonucleosa enzyme to distinguish genes using the 16S rDNA RFLP method is basically not easy. Enzyme Alul (5'AGCT) is not effective to be used in the primary RFLP testing of MS, but the enzyme Haelll (5'GGCC) can provide a clear difference between the five iso- lates of A. salmonicida either by using the primers MS or 16S. The RFLP test on isolates of atypical A. salmonicida on MS rDNA showed that the isolate number 2 (from Yogyakarta) is very different from the other 4 isolates based on the use of Mbol (5'NGATCN) and Ehel (5'GGCGCC) enzymes.

Restriction enzyme that can provide the best result for RFLP method of A.salmonicida is Haell, followed in order of accuracy by Mbol and Ehel enzymes.

\section{REFERENCES}

Austin, D.A., Robertson, P.A.W., Wallace, D.K., Daskalov, H., \&Austin, B. 1998. Isolation of A. salmonicida in Association with PurplePigmented Bacteria in Sediment from Scottish Loch. Lethers in Applied Microbiology, 27: 349- 351.

Austin, B. \& Austin, D.A. (Editor). 1999. Bacterial Fish Pathogens: Diseases of Farmed and Wild Fish, $3^{\text {rd }}$ edd. Chichester : SpringerPraxis.

Borrell, N., Acinas, S.G., Figueras, M.J., \& Martinez- Murcia, A.J. 1997. Identification of Aeromonas salmonicida Clinical Isolates by Restriction Fragment Length Polymorphism of PCR-Amplified 16s rRNA Genes. Journal of Clinical Microbiology, 35(7) : 1,671-1,674.

Brown, T.A. 2002. Genomes. $2^{\text {nd }}$ Edition. Oxford: Wiley- Liss.

Fehr, D., Burr, S.E., Gibert, M., Jacques d'Alayer, Frey, J., \& Popoff, M.R. 2007. Aeromonas 
Indonesian Aquaculture Journal Vol.6 No.2, 2011

Exoenzyme of Aeromonas salmonicida is a Bifunctional Protein That Targets The Host Cytoskeleton. JBC Papers in Press. Published. Copyright by The American Society for Biochemistry and Molecular Biology, Inc.

Figueras, M.J., Soler, L., Chacon, M.R., Guarro, J., \& Martinez-Murcia, A.J. 2000. Extended Method for Discrimination of Aeromonas spp. By 16s rDNA RFLP Analysis. International Journal of Systematic and Evolutionary Microbiology, 50: 2,069- 2,073.

Graf, J. 1999. Diverse Restriction Fragment Length Polymorphism Patterns of the PCRAmplified 16s rRNA Genes in Aeromonas veronii Strains and Possible Misidentification of Aeromonas species. Journal of Clinical Microbiology, 37(10): 3,194- 3,197.

Hiney, M., Dawson, M.T., Heery, D.M., Smith, P.R., Gannon, F., \& Powell, R. 1992. DNA probe for Aeromonas salmonicida. Appl. Environ. Microbiol., 58(3): 1,039-1,042

Huys, G., Kampfer, P., Altwengg, M., Coopman, R., Janssen, P., Gillis, M., \& Kersters, K. 1997. Inclusion of Aeromonas DNA hybridization Group 11 in Aeromonas encheleia and extended descriptions of the species Aeromonas eucrenphila and A. encheleia. Int. J. Syst. Bacteriol., 47: 1,157- 1,164.
Inglis, V., Robert, R.J., \& Bromage, N.R. 1993. Bacterial Disease of Fish. Institute of Aquaculture. Blackwell Scientific Publication. Oxford, p. 122- 142.

McCarthy, D.H., \& Roberts, R. J. 1980. Furunculosis in Fish-The Present State of Our Knowledge In : Advance In Aquatic Microbiology. Academic Press. London, p. 293341.

O'Brien, D., Mooney, J., Ryan, S., Powell, E., Hiney M., Smith, P. R., \& Powell, R. 1994. Detection of Aeromonas salmonicids, Causal Agents of Furunculosis in Salmon Fish, from the Tank Effluent of Hatchery- Reared Atlantik Salmon Smolts. Applied and Environmental Microbiology, 60(10): 3,8743,877 .

Sakazaki, R. \& Balows, A. 1981. The Genera Vibrio, Plesimonas, and Aeromonas, p. 1272- 1301. In. M.P. Starr, H.G. Triper, A. balows, and H.G. Schlegel (ed) The Prokaryotes : a Handbook of Habitats, Isolation, and Identification of Bacteria. SpringerVerlag, New York.

Untergasser. 1989. Hand Book of Fish Diseases (Translated by Howard, H.H) T.S. Hublication, Insc. USA, 33 pp. 